595.77 ENSECTS/MOSQUTOES

JNSF $23-1-17$

J. Natn. Sci. Coun. Sri Lanka 1995 23(1): 17-24

\title{
PRODUCTION AND CHARACTERIZATION OF MONOCLONAL ANTIBODIES TO ANOPHELES TESSELLATUS MUGUT
}

\author{
MANTHRI S. RAMASAMY ${ }^{1}$, R. KULASEKERA ${ }^{1}$, K.A. SRIKRISHNARAJ ${ }^{1}$, \\ JOAN HOOGENRAAD ${ }^{3}$, N.J. HOOGENRAAD ${ }^{3}$ and R. RAMASAMY ${ }^{2}$ \\ 1 Molecular Entomology and ${ }^{2}$ Immunology Laboratories, Division of Life Sciences, \\ Institute of Fundamental Studies, Hantana Road, Kandy. \\ 3 School of Biochemistry, LaTrobe University, Bundoora, Victoria 3083, Australia.
}

(Received : 5 August 1994; accepted: 20 January 1995)

\begin{abstract}
The production of monoclonal antibodies (Mabs) against antigen derived from the midgut of Anopheles tessellatus is described. Three cloned Mabs examined were found to be directed against conformational epitopes on midgut antigens. Ingestion of these Mabs in a bloodmeal did not affect mosquito mortality or fecundity. The intake of the Mabs, when compared to normal mouse IgG, with a bloodmeal containing Plasmodium vivax gametocytes did not reduce the susceptibility of the mosquito to parasite infection.
\end{abstract}

Key words: Anopheles tessellatus, conformational epitopes, monoclonal antibodies, mosquito midgut.

\section{INTRODUCTION}

The midgut of the mosquito is composed of a single layer of epithelial cells and plays an important role in mosquito-pathogen interactions. The ingested bloodmeal is digested in the lumen of the midgut by proteolytic enzymes secreted by midgut epithelial cells. ${ }^{1}$ The sexual stages and ookinetes of the malaria parasite Plasmodium can be damaged by mosquito trypsin. ${ }^{2}$ The formation of a peritrophic membrane by secretions from the epithelium and the presence of receptors on the epithelium for ookinetes also have a function in establishing a Plasmodium infection in the vector mosquito. ${ }^{3}$

Cellular and humoral immune responses against arthropod vector antigens in vertebrate hosts influence vector physiology and modulate the transmission of pathogens. ${ }^{4}$ Midgut antigens have been implicated as the targets for such immune mechanisms. ${ }^{4}$ Immune sera produced in rabbits $^{5}$ and mice $^{6}$ against mosquito tissues (including midguts from non-blood fed Anopheles tessellatus Theobald) reduced mosquito fecundity and its susceptibility to $P$. vivax. ${ }^{7}$ Fecundity reduction has been attributed to antibodies binding to target antigens in the gut, causing it to become leaky and thereby permitting other antibodies to enter the haemocoel to interfere with normal physiological processes. ${ }^{5}$

Monoclonal antibodies (Mabs) produced by hybridoma cultures ${ }^{8}$ represent $^{-}$ one of the many different antibodies produced by conventionally immunized animals. Mabs have been used as probes for investigating mosquito trypsin ${ }^{9}$ and yolk proteins. ${ }^{10-12}$ It is possible that Mabs to midgut antigens are more effective than polyclonal sera in influencing mosquito fecundity and its infectivity to malaria parasites because they can be used at high concentrations against 
specific target molecules. Once biological activity is established characterization of target antigens is also more easily done with Mabs. This paper describes the production and characterization of three Mabs against midgut antigens of An. tessellatus.

\section{METHODS AND MATERIALS}

Midgut antigen: Midguts from 2-3 day old sugar fed female An. tessellatus maintained in the laboratory ${ }^{13}$ were dissected in phosphate buffered saline (PBS) $\mathrm{pH} 7.2$ at $4^{\circ} \mathrm{C}$ and stored at $-20^{\circ} \mathrm{C}$ until used for preparation of antigen. Midguts from 50 mosquitoes were pooled, homogenized and then lyophilized.

Immunization of mice: Lyophilized antigen was reconstituted in distilled water at a concentration of approximately $0.5 \mathrm{mg} / \mathrm{ml}$ protein. Balb/c mice were injected intra-peritoneally with $0.2 \mathrm{ml}$ antigen as a 1:1 emulsion with Freund's complete adjuvant. A second immunization with $0.2 \mathrm{ml}$ antigen was performed as a 1:1 suspension of Freund's incomplete adjuvant 3 wks later. The mice were boosted $12 \mathrm{wks}$ later with $0.15 \mathrm{ml}$ antigen without adjuvant and the spleen removed for fusion 3d later.

Monoclonal antibody production and assay: Spleen cells from two immunized mice were pooled and fused with cells of the non-immunoglobulin secreting myeloma cell line, Ag8-653 in 38\% polyethylene glycol according to established techniques. 8,14 The cells were cultured in medium containing hypoxanthine, aminopterin, thymidine (HAT) in 96 and 24 well plates. A dot immunobinding assay modified from Hawkes ${ }^{15}$ was carried out to screen hybridoma culture supernatants for antibodies. Midgut antigen was applied directly (at 1-2 midgut equivalents/ spot) onto a nitrocellulose filter marked with a grid, air dried and then treated with $3 \%$ bovine serum albumin for $3 \mathrm{~h}$ to block non-specific binding sites on the filter. Hybridoma culture supernatants (first antibody) were added individually onto each antigen spot for $2 \mathrm{~h}$ at $23^{\circ} \mathrm{C}$; the filters were washed in PBS and then incubated with peroxidase conjugated sheep anti-mouse immunoglobulin (Silenus, Australia) for $1 \mathrm{~h}$ at $23^{\circ} \mathrm{C}$. The reaction was visualized with chloronaphthol and $\mathrm{H}_{2} \mathrm{O}_{2} \cdot{ }^{16}$ Four hybridomas identified as positive in the immunobinding assay were cloned by limiting dilution in 96 well plates in a medium containing spleen cells. When clones were well grown, the culture supernatants were tested again by the immunobinding assay for specific antibodies. Strongly positive clones each derived from hybridomas P1G4, 24C6 and 24D4 were grown in 24 well plates and then propagated in tissue culture flasks. Ascites were produced by injecting $5 \times 10^{5}-10^{6}$ cloned hybridoma cells into pristane or Freund's incomplete adjuvant ${ }^{14}$ primed Balb/c mice. Control ascites were produced by injecting Ag8-653 cells. Ascites fluid was tapped, and proteins precipitated with ammonium sulphate, dialysed against 3 changes of $5 \mathrm{mM}$ sodium phosphate ( $\mathrm{pH}$ 6.5) and immunoglobulin IgG purified by DEAE chromatography. ${ }^{14}$ 
Characterization of antigens: Midguts from 300 mosquitoes in $300 \mu l$ PBS was mixed with $500 \mu \mathrm{l}$ of $2 \mathrm{x}$ concentrated Laemmli sample buffer ${ }^{17}$ and placed in boiling water for $3 \mathrm{~min}$ and then subjected to electrophoresis on a $10 \%$ polyacrylamide gel containing sodium dodecyl sulphate (SDS-PAGE). ${ }^{17}$ Moleculer weight standards (Sigma, USA) were subjected to electrophoresis in parallel lanes. Following electrophoresis, the proteins were transferred to nitrocellulose membranes ${ }^{18}$ and strips of the blotted proteins probed ${ }^{19}$ with 1:5 dilutions of hybridoma culture supernatants, purified IgG at $0.05 \mathrm{mg} \mathrm{ml}^{-1}$, immune mouse serum at 1:500 dilution (prepared from the midgut immunized mice from which spleens were removed for fusion), rabbit anti-midgut serum ${ }^{5}$ (1:500 dilution), and unimmunized mouse and rabbit sera (at 1:50 dilution). Peroxidase conjugated rabbit anti-mouse IgG or goat anti-rabbit IgG (Sigma, U.S.A.) at 1:500 dilution was used as the second antibody. Antigen - antibody binding was visualized using a chemiluminescent detection system (Amersham, UK) or chloronaphthol and $\mathrm{H}_{2} \mathrm{O}_{2}$.

Assays for effects of Mabs on mosquito fecundity, mosquito mortality and parasite transmissibility: Mice producing ascites were restrained and used to blood feed groups of 3-4 day old An. tessellatus on two consecutive days. These mosquitoes were held for $72 \mathrm{~h}$ post bloodmeal and dissected to determine the numbers of mature oocytes (eggs) produced. ${ }^{6}$ Mortality was recorded daily during this period. $\mathrm{Mab}$ IgG $(100 \mu \mathrm{l})$ was reconstituted in $200 \mu \mathrm{l}$ normal rabbit serum, mixed at $50 \%$ haematocrit with human erythrocytes parasitized with $P$. vivax gamatocytes and fed to 3-4d old An. tessellatus through a membrane feeder as described previously. ${ }^{7}$ The final concentration of IgG in the bloodmeal was $0.7 \mathrm{mg} \mathrm{ml}^{-1}$. The susceptibility of $P$. vivax to An. tessellatus was determined by counting the numbers of oocysts on the midgut of the mosquito, $10 \mathrm{~d}$ post-infection.

\section{RESULTS}

After fusion, hybrid cells were observed in 58\% of wells. Hybridomas P1G4, 24D4, 24C6, 24C5, P1C11, P1F10, P2C8 produced antibodies that reacted with midgut antigens in immunobinding assays. Of these, the 3 hybridomas that gave the strongest antibody responses, P1G4, 24D4 and 24C6 were cloned by limiting dilution. Over time, the many other hybridomas lost their reactivity with midgut antigen. A typical result obtained in an immunobinding assay with P1G4, 24C6 and other Mabs is shown in Figure 1.

In Western blots, the polyclonal mouse serum and rabbit serum ${ }^{5}$ reacted with electrophoretically separated proteins from the midgut (Fig. 2). Antigens recognized ranged in molecular weight, $M_{r}$ from 20 to $>150 \mathrm{kDa}$. Immune mouse serum recognized prominent antigens of $\mathrm{M}_{r} 20,31-32,47-50,78-80,96-100,107$, 115,120 and $>150 \mathrm{kDa}$. Normal mouse serum showed weak recognition of proteins of $M_{r} 78-80,96-100$ and $107 \mathrm{kDa}$. Similarly, proteins of 26-29, 38-49, $54-58,70-74,78-82,87-88,93,96-100,103-105,110,115,120,145$ and $>150 \mathrm{kDa}$ were detected with immune rabbit serum, ${ }^{5}$ while weak reactions of proteins of molecular weight 64-70 and 78-82 kDa were observed with normal rabbit serum. In addition, a protein of $86 \mathrm{kDa}$ molecular weight reacted weakly with the 
unimmunized rabbit serum. None of the Mabs (hybridoma supernatants, ascites fluid) reacted with midgut antigen in Western blots when antibody binding was visualized by either chemiluminiscence or with chloronaphthol.

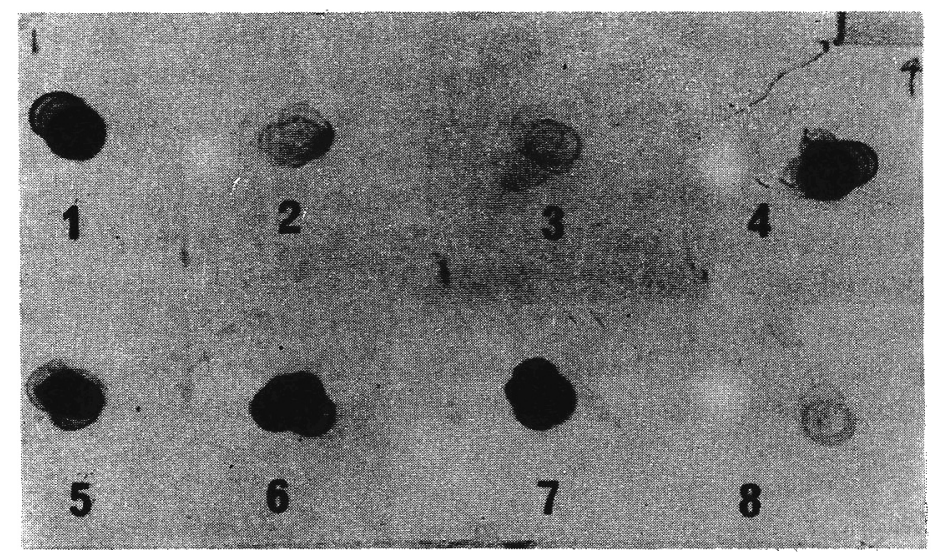

Figure 1: Immunobinding of hybridoma supernatants to An. tessellatus midgut antigen. 1. P1G4, 2. P1F10, 3. P2C8, 4. mouse anti-midgut serum (+ve control), 5. 24C6, 6. P1G4F4 7. P1G4D5, 8. culture medium (-ve control).

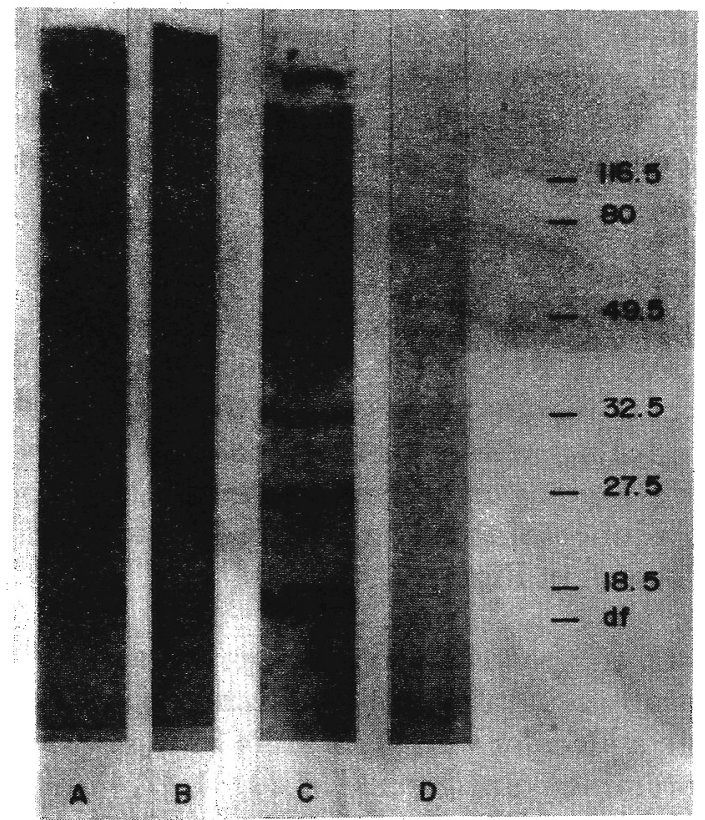

Figure 2: Western blots of An. tessellatus midgut antigens reacting with A. rabbit anti-midgut serum, B. non-immune rabbit serum, C. mouse anti-midgut serum and D. non-immune mouse serum Migration positions of pre-stained molecular weight markers (Sigma, USA) are indicated in $\mathrm{kDa}$. $\mathrm{df}=\mathrm{bromophenol}$ blue dye front. 
The results of immunobinding assays using denatured antigens is shown in Table 1 . Denaturing midgut antigen with $0.1 \%$ SDS alone at room temperature $\left(23^{\circ} \mathrm{C}\right)$ was sufficient to reduce the affinity of the antibody binding. Mercaptoethanol, which reduces disulphide bonds, acted synergistically with SDS in reducing reactivity.

Table 1: Immunobinding capacity of denatured midgut antigens.

\begin{tabular}{|c|c|c|c|c|}
\hline \multirow{2}{*}{ Denaturing agent } & \multirow[t]{2}{*}{$\mathrm{Temp}^{\circ} \mathrm{C}$} & \multicolumn{3}{|c|}{ Colour reaction } \\
\hline & & P1G4E7 & 24C6E9 & $24 \mathrm{D} 4 \mathrm{C} 4$ \\
\hline $2 \% \mathrm{SDS}$ & & & & \\
\hline $5 \%$ Mercaptoethanol & $50^{\circ} \mathrm{C}$ & 0 & 0 & 0 \\
\hline $2 \% \mathrm{SDS}$ & $50^{\circ} \mathrm{C}$ & +1 & +1 & +1 \\
\hline PBS (control) & $\mathrm{RT}\left(23^{\circ} \mathrm{C}\right)$ & +4 & +4 & +4 \\
\hline $2 \% \mathrm{SDS}$ & & & & \\
\hline $5 \%$ Mercaptoethanol & $\mathrm{RT}\left(23^{\circ} \mathrm{C}\right)$ & 0 & 0 & 0 \\
\hline $0.1 \% \mathrm{SDS}$ & $\mathrm{RT}\left(23^{\circ} \mathrm{C}\right)$ & +3 & +2 & +1 \\
\hline
\end{tabular}

Denaturation was carried out for $15 \mathrm{~min}$ at each temperature. Ascites fluid was used as the first antibody. RT - room temperature. Intensity of colour development: 0 (no colour) to +4 (maximum).

Mice injected with cloned hybridoma cells P1G4E7, 24D4C4, 24C6E9 (i.e. from parent cells P1G4, 24C4 and 24C6) and control Ag8-653 cells showed serum antibody titres of $10^{6}, 10^{6}, 10^{5}$ and $10^{2}$ respectively in immunobinding assays. Mosquitoes engorged readily on immunized and control mice and the presence of anti-midgut antibodies did not influence the fecundity of the mosquitoes. The numbers of mature oocytes (eggs) produced by An. tessellatus feeding on antibodies to $24 \mathrm{DC} 4$ were $53.3 \pm 3.5(\mathrm{n}=50)$ while in the same experiment mosquitoes feeding on control Ag8-653 ascites produced 59.4 \pm 3.5 $(\mathrm{n}=50)$ mature oocytes. In another experiment mosquitoes feeding on mice with ascites to P1G4E7 and 24C6E9 produced $58.3 \pm 1.41(\mathrm{n}=49)$ and $59.5 \pm 1.51$ ( $n=53$ ) oocytes while An. tessellatus feeding on a control Ag8-653 injected mouse produced $56.1 \pm 1.41(\mathrm{n}=50)$ mature oocytes.

The presence of IgG from the Mabs, 24D4C4 and 24C6E9 in the bloodmeal reduced the susceptibility of An. tessellatus to $P$. vivax (Table 2 ) ; in these experiments, the presence of IgG antibodies from Ag8-653 ascites also reduced the susceptibility of the vector, when compared to the absence of mouse IgG. Immunoglobulin (IgG) from the Mab P1G4E7 did not have a significant effect on the susceptibility of the vector to $P$. vivax (data not shown). The mortality of An. tessellatus was not increased by ingesting Mabs - (either from ascites or IgG) in a bloodmeal (data not shown). 
Table 2: Effect of monoclonal IgG on the infectivity of P. vivax to An. tessellatus.

\begin{tabular}{ccc}
\hline Hybridoma & $\begin{array}{c}\text { IgG concentration in } \\
\text { bloodmeal }(\mathrm{mg} / \mathrm{ml})\end{array}$ & \% Infectivity (n) \\
\hline Experiment 1 & & $38(50)^{\mathrm{a}}$ \\
PBS & - & $21.9(64)^{\mathrm{a}}$ \\
Ag8-653 & 0.7 & $19.4(67)$ \\
24D4C4 & 0.7 & $29.4(68)$ \\
24D4C4 & 0.07 & \\
Experiment 2 & & $23.2(69)^{\mathrm{b}}$ \\
PBS & & $12.4(89)^{\mathrm{b}}$ \\
Ag8-653 & 0.7 & $17.8(84)$ \\
24C6E9 & 0.7 & $16.2(68)$ \\
24C6E9 & 0.07 & $13.6(59)$ \\
Combination of & & \\
three Mabs* & & \\
\hline
\end{tabular}

* A mixture of P1G4E7, 24D4C4 and 24C6E9 each at a final concentration of $0.3 \mathrm{mg} / \mathrm{ml}$ in the bloodmeal ${ }^{\mathrm{a}} \chi^{2}=3.55, \mathrm{p}>0.05 ;{ }^{\mathrm{b}} \chi^{2}=3.2, \mathrm{p}>0.05$.

\section{DISCUSSION}

The reaction of the three Mabs with An. tessellatus midgut antigen in immunobinding assays and not in Western blots is likely to be due to the antibodies being directed against conformational epitopes on midgut antigens. Since the polyclonal sera used as controls detected a number of protein bands on Western blots, it is likely that they contain antibodies directed against a significant number of non-conformational epitopes on midgut antigens. Some midgut antigens reacted weakly with antibodies from unimmunized mice and rabbits probably due to cross-reaction with antigens of common gut bacteria. In immunobinding assays, the target antigens of Mabs were also detected in head/thorax and abdomen of An. tessellatus but not in midguts of Culex quinquefasciatus (data not shown). Cross-reactivity has been previously demonstrated between tissue of the head/ thorax, abdomen and midgut of An. tessellatus. ${ }^{16}$ The absence of reactivity with midgut of $C x$. quinquefasciatus suggests that these Mabs are directed against species-specific midgut antigens.

The Mabs had no biological activity in the assays on fecundity, mortality and parasite infectivity when compared to normal mouse IgG (from Ag8-653 ascites) used as a control. However, normal mouse IgG (from Ag8-653 ascites) had a consistent (not statistically significant, $p>0.05$ ) effect in reducing the susceptibility of An. tessellatus to $P$. vivax when compared to the absence of mouse IgG in the bloodmeal. This may be due to the presence of small quantities of natural antibodies that react with An. tessellatus molecules. It is not clear whether the lack of an effect with the three Mabs is due to the nature of the target antigen, the conformational nature of the epitopes or both. Molecular characterization of 
the target antigens was made difficult by the conformational nature of the epitopes involved. Identifying biologically useful Mabs involves quite difficult technical procedures and also may require the screening of a large number of Mabs for biological activity. The production of monospecific, polyclonal sera directed against specific purified proteins of the gut may be an alternative approach towards the same objective.

\section{Acknowledgement}

This investigation received partial financial support from the International Atomic Energy Agency, the UNDP/ World Bank/ WHO Special Programme for Research and Training in Tropical Diseases and the Natural Resources Energy and Science Authority of Sri Lanka (RG/92/B/9). We thank S. Jayaweera and L. Ratnayake for technical assistance, and V. Udawatta for typing the manuscript.

\section{References}

1. Briegel H. \& Lea A.O. (1975). Relationship between protein and proteolytic activity in the midgut of mosquitoes. Journal of Insect Physiology 21: 15971604.

2. Gass R.F. (1977). Influence of blood digestion on the development of Plasmodium gallinaeceum (Brumpt) in the midgut of Aedes aegypti (L). Acta Tropica 34: 127-140.

3. Ponnudurai T., Billingsley P.F. \& Rudin W. (1988). Differential infectivity of Plasmodium for mosquitoes. Parasitology Today 4: 319-321.

4. Ramasamy R. \& Ramasamy M.S. (1990). The role of host immunity to arthropod vectors in regulating the transmission of vector borne diseases. Insect Science and its Application 11: 845-850.

5. Ramasamy M.S., Srikrishnaraj K.A., Wijekoon S., Jesuthasan L.S.B. \& Ramasamy R. (1992). Host immunity to mosquitoes: effect of antimosquito antibodies on Anopheles tessellatus and Culex quinquefasciatus (Diptera: Culicidae). Journal of Medical Entomology 29: 934-938.

6. Srikrishnaraj K.A., Ramasamy R. \& Ramasamy M.S. (1993). Fecundity of Anopheles tessellatus reduced by the ingestion of murine anti-mosquito antibodies. Medical and Veterinary Entomology. 7: 66-68.

7. Ramasamy M.S., Srikrishnaraj K.A. \& Ramasamy R. (1993). Studies on the effect of anti-mosquito antibodies on the infectivity of human malaria parasites to vector mosquitoes. In Host Regulated Developmental Mechanisms in Vector Arthropods (Ed. D. Borovsky \& A. Spielman) pp 320-326. University of Florida, U.S.A. 
8. Kohler G. \& Milstein C. (1975). Continuous cultures of fused cells secreting antibody of predefined specificity. Nature 256: 495-497.

9. Graf R., Binz H. \& Briegel H. (1988). Monoclonal antibodies as probes for Aedes aegypti trypsin. Insect Biochemistry 18: 463-470.

10. Ma M., Newton P.B. Gong H., Kelly T.J., Hsu H.T., Master E.P. \& Borkovec A.B. (1984). Development of monoclonal antibodies for monitoring Aedes atropalpus vitellogenin. Journal of Insect Physiology 30: 529-536.

11. Raikhel A.S., Pratt L.H. \& Lea A.O. (1986). Monoclonal antibodies as probes for processing of yolk protein in the mosquito: production and characterization. Journal of Insect Physiology 32: 879-890.

12. Ramasamy M.S., Sands M., Gale J. \& Ramasamy R. (1988). Mosquito vitellin: structural and functional studies with monoclonal antibodies. Insect Science and its Application 9: 499-504.

13. Abeywickreme W., Mendis K.N., Samarakoon S.M.S. \& Nanayakkara S. (1984). Establishment of a free mating colony of Anopheles (Cellia) tessellatus Theobald, 1901 under laboratory conditions. Proceedings of the Sri Lanka Association for the Advancement of Science 40(1): 15-16.

14. Harlow E. \& Lane D. (1988). Antibodies, A laboratory manual. Cold Spring Harbor Laboratory, U.S.A.

15. Hawkes R. (1986). The dot immunobinding assay. Methods in Enzymology 121: $485-491$.

16. Ramasamy R., Nadesalingam P. \& Ramasamy M.S. (1991). Antigenic similarity between the mosquito vectors of malaria and filariasis. Journal of Medical Entomology 28: 760-762.

17. Laemmli U.K. (1970). Cleavage of structural proteins during the assembly of the head of bacteriophage T4. Nature 227: 680-685.

18. Towbin H., Staeheln R. \& Gordon J. (1979). Electrophoretic transfer of proteins from polyacrylamide gels to nitrocellulose sheets. Procedure and some applications. Proceedings of the National Academy of Sciences U.S.A. 76: $4350-4354$.

19. Ramasamy R. (1987). Studies on glycoproteins in the human malaria parasite Plasmodium falciparum. The identification of a myristilated $45 \mathrm{kDa}$ merozoite membrane glycoprotein. Immunology and Cell Biology 65: 419-425. 